In this issue:

Collective Bargaining and Academic Librarians

NELINET-ACRL/NEC Joint

Meeting and Conference

News From the Chapters

Retrenchment in Higher Education

News From the Field

Index

3
5
6
8
$14 a$
23
25

Classified Advertising

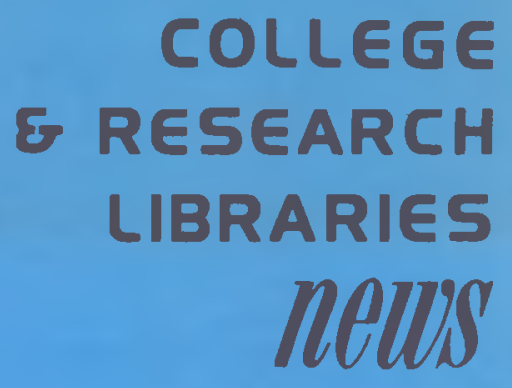

NO. $1 \bullet$ JANUARY 1976

\title{
Collective Bargaining and Academic Librarians: A Review of the Decisions of the NLRB
}

\begin{abstract}
Submitted by
C. James Schmidt

Director of Libraries

State University of New York at Albany Chairman, ACRL Academic Status Committee

As the experience in higher education with collective bargaining becomes more extensive and documented, it is possible to identify trends. Specifically, it is now possible to examine the effects of bargaining unit determination on academic librarians. Are librarians usually included in the unit with other faculty? Which positions within a library are supervisory? What follows is a review of decisions of the National Labor Relations Board (NLRB).

In its first unit determination decision in higher education which specifically mentioned librarians, the board concluded

that these librarians are professional employees within the meaning of Section 2(12) of the Act, are engaged in functions closely related to teaching, and share many of the same benefits as other unit employees. Accordingly, we find they have a community of interest with the faculty and include them in the unit. [Footnote attached excluded library director as supervisor ${ }^{1}$
\end{abstract}

In 1971, in two cases involving Fordham University, the board made the following statement
While the librarians do not have faculty status, it is clear that some of them are professional employees and should be included in the unit. The record does not contain sufficient evidence to determine whether any of them are supervisors.2 [emphasis added]

In the companion case involving the question of a separate unit for the Fordham Law School, the law librarian was excluded from the faculty unit as a supervisor. ${ }^{3}$ Fordham represents the first in a series of cases which have attempted to answer the question whether the academic department chairperson is a supervisor. 4

In 1972 the board included librarians in the faculty unit at Florida Southern and commented that

the librarians have advanced training and possess degrees in library science, are eligible for and in some instances do have tenure, attend and vote at faculty meetings, and in many respects through their functions as librarians in relationship with the members of the student body make substantial contributions to the education of students, we find the librarians are professional employees engaged in functions closely related to teaching and that they have a community of interest with the faculty. Accordingly, we shall include them within the unit. 5

Also in 1972, in a case involving Tusculum College, ${ }^{6}$ the Board directed the inclusion of the 
librarian and the assistant librarian in the faculty unit based on the rationale used in C. W. Post, cited above.

Since 1972 the board has issued six decisions about unit definition in higher education which mention librarians, ${ }^{7}$ and, in all cases, librarians, if not excluded as supervisors, have been included in the faculty unit.

The record of the NLRB clearly indicates that it has consistently included librarians in the faculty unit based on a prima facie acknowledgment by the board that librarians are professionals within the meaning of the National Labor Relations Act and that there is sufficient affinity of function between faculty and librarians to create a community of interest for purposes of collective bargaining.

There are two grounds under which the NLRB may have excluded librarians from faculty units. The first, reviewed above, was community of interest. The second is the issue of "supervisor" which was mentioned above but not discussed in detail. In general the board seems to have had more difficulty defining the "supervisor" in its dealings with higher education than in other fields. One of the most divisive unresolved issues in academic collective bargaining is the role of the department or division head: management or labor?

The cases reviewed above for their treatment of librarians in unit determinations also raise the question of "supervisor" in the library context. The board's answer seems to still be inconsistent. The criteria applied by the board to head librarians seem to be three: (a) degree of real authority and autonomy; (b) whether other employees in the same bargaining unit are subordinates; (c) the fifty percent rule. ${ }^{8}$ In the New York University case the board said

. . . we reject the Employer's contention that all professional librarians possess supervisory authority over nonunit employees to a degree requiring their exclusion. ${ }^{9}$ [emphasis added]

we shall exclude as supervisors only those professional librarians who supervise other employees in the unit or who spend more than fifty percent of their time supervising nonunit employees. ${ }^{10}$

The most celebrated NLRB case on the question of the supervisor in academic libraries involved an allegation of unfair labor practice at the University of Chicago.11 Inclusion of librarians in a faculty unit was not at issue in this case, there being no faculty unit at the University of Chicago in 1972. The board ruled against the university and issued a cease and desist order on the ground that the practices alleged were engaged in by a person(s) who was a supervisor within the meaning of the National Labor Relations Act. The University appealed this decision to the U.S. Court of Appeals, 7 th
Circuit. The court, in an unpublished order, upheld the board.12 Both the board and the court explicitly leave open the question of whether persons determined to be supervisors for purposes of deciding unfair practice issue would also be determined to be supervisors in a representation case.

Thus, the current criteria for excluding academic librarians from a bargaining unit on a selective basis as supervisors seem to be those used in the NYU case cited above.

A brief comment should also be made on the Claremont case. ${ }^{13}$ The question at issue in this case was not inclusion of librarians in the unit with faculty, there being no faculty unit, nor the issue of librarian as supervisor, but rather whether professionals and nonprofessionals in the Honnold (Claremont) Library System constitute an identifiable group of employees with a community of interest. The board ruled that the nonprofessionals in the Claremont Libraries did constitute an appropriate unit for bargaining in that these employees did have a community of interest separate from that of other nonprofessional (i.e., clerical) employees at Claremont. However, the board also noted that it was prevented by provisions of the National Labor Relations Act from ordering the inclusion of professionals (librarians) in a bargaining unit of nonprofessionals, but that the librarians could elect to be included in the unit with nonprofessionals. Subsequently, those librarians determined not to be supervisors did elect to be included in the nonprofessional unit.

News ifems for inclusion in C\&RL News should be sent to Mary Frances Collins Assistant Director of Libraries for Technical Services, University Library ULB-35A, State University of New York at Albany, 1400 Washington Ave. Albany, NY 12222. Advertising (including classified ads) should be sent to Leona Swiech, Advertising Office, American Library Association 50 E. Huron St. Chieago, IL 60611 . Production and circulation matters are handled by ALA Central Production Unit, at the above address.

News editor: Mary Frances Collins Assistant Di rector of Libraries for Technical Services. State University of New York at Albany, Albany. Associate News editor: Anne Dowling, Assistant Libbrarian. Acquisitions Department, Library, State University of New York at Albany. Editor: Richard D. Johnson, Milne Library, State University College, Oneonta. New York 13820. President, ACRL: Louise Giles. Executive Secretary, ACRL Beverly P. Lynch.

College Research Libraries is published by the Association of College and Research Libraries, a division of the American Library Association, 17 times yearly- 6 bimonthly journal issues and II manthly (combining July-August) News issues-at I201-05 Bluff St. Fulton, MO 65251. Subseription. $\$ 15.00$ a year or to members of the division. $\$ 7.50$ included in dues. Second-class postage paid at Fulton, Missouri 65251.

(C) American Library Association 1976. All material in this journal subject to copyright by the American Library Association may be photocopied for the noncommercial purpose of scientific or edueational advancement. 
The experience of academic librarians in the public sector with respect to unit determination is not under the jurisdiction of the NLRB, but is rather governed by state law and/or boards. As such it is appropriately the subject of another review and is beyond the intended scope of the essay. Readers are reminded that the scope of bargaining units can also be set by consent such that it is possible that librarians may not be in the unit with faculty by agreement between bargaining agent and employer.

\section{Rearerences}

1. C. W. Post Center of Long Island University 189 NLRB 906 (1971).

2. Fordham University 193 NLRB 139 (1971).

3. Ibid, 140, note 23.

4. For a review of the arguments see Ralph E. Kennedy, "The Educator's Role in Educating the NLRB." Journal of College and
University Law (Summer 1974), p.308-11.

5. Florida Southern College 196 NLRB 889 (1972).

6. Tusculum College 199 NLRB 31 (1972).

7. Catholic University 201 NLRB 145 (1973); New York University 205 NLRB 16 (1973); University of San Francisco 207 NLRB 15 (1973); Point Park College 209 NLRB 152 (1974); Fordham University 214 NLRB 37 (1974); Rensselaer Polytechnic Institute 218 NLRB 220 (1975).

8. Adelphi University 195 NLRB 639 (1972).

9. 205 NLRB 16 ( 1973 ).

10. Ibid.

11. University of Chicago Library 205 NLRB 44 (1973).

12. University of Chicago vs. NLRB (unpublished order \#73-1788, Case 13-CA11447 ).

13. 198 NLRB 121 ( 1972$).$

\section{NELINET - ACRL/NEC Joint Meeting and Conference}

\section{Reported by \\ Jacqueline Seuss \\ Acquisitions Librarian \\ Boston College}

Because of a common interest in developing simple cost measures for use in libraries, the membership of NELINET and the membership of the ACRL-New England Chapter met together in a joint meeting and conference chaired by Gai Carpenter, NELINET Executive Committee and director of the Harold F. Johnson Library Center, Hampshire College, at the New England Center for Continuing Education in Durham, New Hampshire, on Friday, November 14, 1975.

In the morning separate business meetings were held by each group. The business meeting of the ACRL-New England Chapter will be reported separately in the February issue of $C \& R L$ News under "News from the Chapters." Reporting to the NELINET membership, Robert F. Miller, the director of NELINET, highlighted recent activities in which NELINET has been engaged, namely, further democratizing the governance system and accessing the impact of the recent OCLC rate increase. Future activities to be given high priority, he stated, were (1) to resolve the future of the Northeast Academic Science Information Center (NASIC), (2) to complete by December the National Agricultural Library project, and (3) to conclude negotiations with OCLC. Also reporting at the NELINET business meeting was Frederick G. Kilgour, director of the Ohio College Library Center. Mr. Kilgour stated that the biggest problem facing OCLC was that of capitalization, explaining that funds for capital expenditure must now be provided by the users rather than the vendors. Using the Ohio experience by way of illustration, he estimated that the recent rate increase amounted to only 13 percent while at the same time usage had increased 18 percent. After briefly summarizing the accomplishments of the OCLC system, he outlined expansion of service in 1976 into the areas of automated check-in, acquisitions, interlibrary loan, and subject retrieval.

Upon completion of the business meetings, the joint conference was opened by an address entitled "Library Cost Analysis: What We Need to Know and Why" by Sherrie S. Bergman, librarian, Wheaton College. Budget justification, Ms. Bergman pointed out, is one of the primary reasons for employing more sophisticated analyses, the traditional approach of circulation figures, for example, often being inadequate and misleading. Almost any library operation can be measured, she said, and the relationship between cost and production can be established. Ms. Bergman suggested that after the librarian has selected the specific areas of study, several basic principles of cost analysis should be remembered: measurement almost always contains error and only a level of precision that is acceptable need be applied; the 